\title{
THE EFFECT OF ACCOUNTABILITY, TRANSPARENCY, OPENNESS, FAIRNESS AND COMPETITION ON EFFECTIVENESS AND EFFICIENCY OF E-PROCUREMENT IN MALUKU PROVINCIAL PROCUREMENT SERVICES UNIT
}

\author{
Surijadi Herman \\ Ambon State Polytechnic, Indonesia \\ Tamaela Eduard Yohannis* \\ Administrative Sciences College Said Perintah Masohi, Indonesia \\ *E-mail: tamaelaeduard@gmail.com
}

\begin{abstract}
The purpose of this study is to examine and analyze the influence of accountability and transparency principles, open, fairness and competition against e-procurement effectiveness and efficiency in procurement service unit Maluku Province. The population of this study was all participants or providers of government Goods/Services registered in procurement service unit Maluku Province with purposive sampling as a sample method with 79 participants or providers of government Goods/Services as respondents. Data collection was done by direct survey. Hypothesis testing was empirically tested using Multiple Linear Regression Analysis. The results showed that the principle of accountability and transparency, openness, fairness / non-discrimination and competition proved to have a positive and significant impact on the effectiveness and efficiency of e-procurement in procurement service unit Maluku Province. This can be proven through regression coefficient indicating that if the principle of accountability and transparency, openness, fairness / non-discrimination and competition increase, then it will be followed by improvement of effectiveness and efficiency of eprocurement at procurement service unit Maluku Province. Thus, it can be said that increasing the principles of accountability and transparency, openness, fairness / nondiscrimination and competition will improve the effectiveness and efficiency of e-procurement in procurement service unit Maluku Province.
\end{abstract}

\section{KEY WORDS}

Accountability, transparency, openness, competition, effectiveness, efficiency.

The demand for good governance in Indonesia arose due to the rampant practices of government officials. The number of cases of law violations and power abuse committed by the elements in the Indonesian government become a dilemma and of course is a barrier in realizing good governance. One of the most frequent cases of lawlessness is corruption.

In an article on the Ministry of Finance's Education and Training of Finance website, for example, it is said that the most corruption handled by the Corruption Eradication Commission related to corruption is in the procurement of government Goods/Services and is the second highest corruption case after bribery case. In 2004-2010 period, $44 \%$ of corruption cases handled by KPK were corruption cases in the government procurement (www.bppk.kemenkeu.go.id).

One of the implementation to realize good governance in Indonesia especially concerning regulate procurement policy of goods/services, then issued Presidential Regulation No. 54 of 2010 on Procurement of Government Goods/Services in order to provide guidance on regulation on the procedure of procurement of Goods/Services is simple, clear and comprehensive, in accordance with good governance through joint financing schemes (cofinancing) between the central government and local government. Presidential Regulation No.54 of 2010 was then revised to Presidential Regulation No. 70 of 2012 and then revised again to Presidential Regulation No. 4 of 2015. 
The existence of this e-procurement system as the front guard in guarding the credible procurement process, not without weaknesses. As stated by the Head of Government Procurement Policy Agency, Agus Rahardjo who argued that in 2014 e-tendering funds reached Rp. 304 trillion while e-purchasing (direct appointment) reached Rp. 15 trillion. Of the total R.p 820 trillion procurement of government goods and services', it means that about $38 \%$ are realized (http://www.medanbisnisdaily.com). This fact proves that there are still irregularities that occur in the e-procurement system.

The above facts indicate that the implementation of e-procurement should still receive attention to perform its function as a guardian of the procurement process of credible government goods/services. This is necessary because in essence this system aims to reduce the losses of the country born due to the use of conventional system (manual purchase). This statement is reinforced by research results Panayitou et al. (2004) proves that e-procurement can reduce supply cost (average $1 \%)$, reduce cost per tender $(20 \%$ cost per tender), lead time savings (4.1 month - 6.8 months for open tender and 7.7 months - 11.8 months for limited tender).

This statement is in line with the findings of Wahyu Hary Wijaya, et al. (2011) which states that the variables affecting procurement efficiency include reducing cost per tender and reducing procurement process time and will be highly profitable in the future. Other researchers namely V.K. Narendira Kumar and B. Srinivasan, (2013) also stated that several factors affecting the implementation of e-procurement include; cost, supply chain visibility, turnaround time, tender process controls, inventory management and minimize errors in the process of purchasing goods. Badzlina Daroyani Novitaningrum, (2014) also supports the above statement that accountability and transparency in the procurement of goods and services of Surabaya City Government through e-procurement has been successfully realized.

Similar opinion was also delivered by Misbakhul Munir, (2015) which stated that overall implementation of e-Procurement in Lamongan District has been running very well, with details of accountability score $(85.33 \%)$, target $(87.73 \%)$, data security $(84,83 \%)$, fairness / non-discrimination (85\%) and transparency $(87.33 \%)$ are in very effective category. The benefits of the state losses reducing are also submitted by Luh Putu Resti Mega Artantri, et al., (2016) that e-procurement has a role to suppress fraud on the procurement of Goods/Services of local governments on the island of Lombok.

Based on the description of phenomena and empirical studies above it can be said that the determinant of the realization of good e-procurement implementation is the principles of procurement of Goods/Services of the government, among others; effective, efficient, accountable, transparent, open, fair or non-discriminatory, and competitive. The novelty of this research lies in the development or existence of a conceptual model of research, particularly in the incorporation of accountability principles and the principle of transparency. This merger is an existence or model development based on the opinion of Stirton, (2001) who argues that although not identical but transparency is closely linked to accountability which means transparency can be combined with accountability.

This research will then be conducted at the Procurement Services Unit of Maluku Province with the aim to examine and inspect in depth the influence of the principle; accountability and transparency, openness, fairness or non-discrimination, and competition against the effectiveness and efficiency of e-procurement in Maluku Province. Selection of procurement service unit Maluku itself is based on the refutations submitted by the provider to the procurement service unit of Maluku Province and some even to the level of complaint. Disclaimer even complaint of course indicates that the implementation of e-procurement in the procurement process of government goods and services has not been effective and efficient.

\section{REVIEW OF LITERATURE}

Principal-Agent Theory. Jensen, (1976) argues that principal-agent relationships are contracts between one or several persons as principals with one or more persons as agents 
to carry out services for their interests that involve delegating authority to agents. If both parties are interested in maximizing the utility, then the agent will not always apply in the best interests of the principal and potentially irregularities. According to Jensen, (1976) such deviations potentially cause economic losses. Costs incurred in this principal-agent relationship include:

- Costs to ensure that agents make optimal decisions for principal interests include bonding costs by agents and supervisory fees by the principal;

- Residual cost is the cost borne principal due to the divergence between decisions taken by the agent with a decision that can maximize the welfare of the principal.

Contingency Theory. The emergence of contingency theory is the result of criticism of classical theories that advocate "one best way" to organize and manage organizations. Contingency Theory proposes that there is no best way to organize different organizations working in different industries under different conditions. One of the most influential studies in the emergence of contingency theory was the research of Burns and Stalker (1961). They found two different management practices used, which they classified as "mechanistic" and "organic" systems. Mechanical systems are most appropriate for organizations operating under stable conditions. On the other hand, organic systems are more suitable for organizations working under unstable and volatile environments. This system allows the organization concerned to adapt to environmental changes. Burns and Stalker emphasize that any suitable system should also look at certain conditions meaning no system is superior to the other in all situations.

Concept about Public Procurement. Public procurement is politically sensitive because it involves a very significant amount of budget. Based on Presidential Regulation No. $54 / 2010$ on Procurement of Government Goods/services, Procurement of Government Goods/Services is an activity to obtain Goods/Services by Ministry / Institution / Work Unit of Regional Devices / other Institutions whose process starts from planning of needs until completion of all activities to obtain Goods/services. Coverage of procurement activities includes planning, procurement process, receipt and storage, use of goods and asset management, and three transactions ie Goods/Services purchases (contracts), goods receipt transactions and goods disbursement transactions.

The concept of procurement of goods/public services is also submitted by the Organization for Economic Cooperation and Development, (2007) that has conducted a research from the perspective of good governance. The research produces solutions for increased integrity and prevention of corruption in the procurement of public Goods/Services ranging from the stages of determining the needs to contract management. They also revealed that transparency and accountability play an important role in the procurement of public goods/services. This statement is supported by the opinions of Rubinstein, (2007) and Schapper, (2009).

Principles of Procurement of Goods and Services in Indonesia. The principle of procurement of goods and services is based on government regulation through Presidential Regulation Number; 54 of 2010, number 70 of 2012 and number 4 of 2015 which in it describes a number of principles that should be the basis in implementing the procurement process of goods/services.

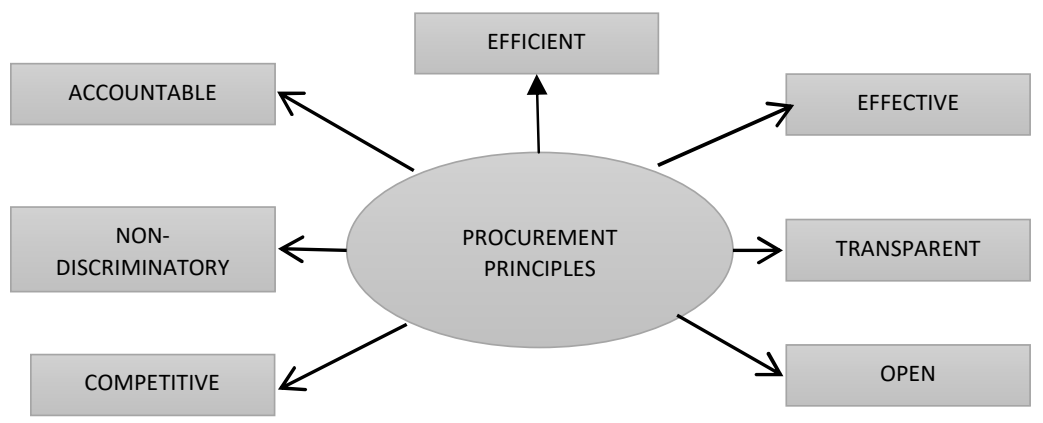

Figure 1 - Principles of Procurement of Goods and Services in Indonesia (Source: Presidential Regulation No. 70 of 2012) 
This whole principle will be implemented in every process of procurement of goods and services, as described below.

- Efficient; procurement efficiency is measured against how much effort is made to obtain Goods/services;

- Effective; the effectiveness of procurement is measured against how far the Goods/Services obtained from the procurement process can reach the specified specifications;

- Transparent; how the whole process of procurement of Goods/Services is done so that it can be known widely covering the provisions, procedures, mechanisms, rules of the game, the specification of Goods/Services and all matters related to how the procurement process of Goods/Services is done;

- Open; procurement of Goods/Services can be followed by all providers of Goods/Services that meet the requirements / criteria established in accordance with applicable regulations;

- Competitive; the procurement process of Goods/Services can create a healthy climate or atmosphere of competition among providers of goods/services, no interventions that can disrupt market mechanisms;

- Fair/Non-Discriminatory; the procurement process may provide equal treatment to all prospective Providers of the Goods/Services and does not lead to profit to a particular party, unless provided for in this rule;

- Accountable; the whole process must be in accordance with the rules and provisions related to the procurement of Goods/Services so it can be accountable.

Previous Research and Research Hypothesis. OECD, (2007) and Schapper, (2009) argue that transparency and accountability are believed to be key factors for improving integrity and preventing corruption in the procurement of goods/services. This opinion reinforces previous statements by Grant, (2005) and Rubinstein, (2007). Wahyu Hary Wijaya, Retno Indryani, and Yusronia Eka Putri, (2011) stated that the variables that positively influence the procurement performance in Surabaya City Government are clean and transparent exports. Similar results were also delivered by Misbakhul Munir, (2015) stated that the overall implementation of e-Procurement in Lamongan District has been running very well, with details of accountable scores $(85.33 \%)$ and transparent $(87.33 \%)$ which are in very effective category. This means that the procurement principles have contributed positively to the implementation of e-procurement.

Badzlina Daroyani Novitaningrum, (2014) stated that accountability and transparency in procurement of goods and services of Surabaya City Government through e-procurement has been successfully realized. Furthermore, previous research by Florensia Br. KJaro-Karo, (2012) proves that the use of e-procurement at the Yogyakarta City government is capable of producing higher levels of efficiency and is able to maintain the confidentiality of offer documents of vendors / providers of goods and services. This statement is also reinforced by Luh Putu Resti Mega Artantri, Lilik Handajani and Endar Pituringsih, (2016) also proves that e-procurement has a role to suppress fraud on procurement of Goods/Services of local government in Lombok Island. Based on the explanation, the hypothesis that is built is as follows:

$\mathrm{H}_{1}$ : The principle of accountability and transparency has a positive effect on the effectiveness and efficiency of e-procurement in procurement service unit Maluku Province.

Another empirical study by A. Ika Iskandar, (2013) reveals that in general the application of procurement principles (including open principles) in the implementation of procurement of government Goods/Services in Government Procurement Policy Institutions, Sukabumi and Government Bogor city has been running but there are still some things that are not in accordance with the provisions. Similar results were also delivered by Misbakhul Munir, (2015) stated that the overall implementation of e-Procurement in Lamongan District has been running very well, with transparent scores or openness $(87.33 \%)$ in the category very effective. Based on the explanation, the hypothesis that is built is as follows: 
$\mathrm{H}_{2}$ : The open principle positively affects the effectiveness and efficiency of eprocurement in procurement service unit Maluku Province.

The results of A.lka Iskandar's (2013) review reveal that in general the application of procurement principles (including Fair/Non-Discriminatory) principles in the implementation of government procurement in Government Goods / Service Procurement Policy Institution (LKPP), Sukabumi and City Government of Bogor. Similar results were also delivered by Misbakhul Munir, (2015) stated that overall implementation of e-Procurement in Lamongan District has been running very well, with details; Fair/Non-Discriminatory (85\%) who are in very effective category. This reality also means that the procurement principle has a positive effect on the implementation of e-procurement. Based on the explanation, the hypothesis that is built is as follows:

$\mathrm{H}_{3}$ : The principle of Fair/Non-Discriminatory has a positive effect on the effectiveness and efficiency of e-procurement in procurement service unit Maluku Province.

The guidance of this final research hypothesis is based on the results of empirical study by A.lka Iskandar, (2013) and Misbakhul Munir (2015) stated that the competitive principle is able to realize or positively affect the effectiveness and efficiency of procurement of Goods/Services in Sukabumi City, Bogor City and Lamongan Regency. Based on the explanation, the hypothesis that is built is as follows:

$\mathrm{H}_{4}$ : The competitive principle positively affects the effectiveness and efficiency of eprocurement in procurement service unit Maluku Province.

\section{METHODS OF RESEARCH}

This research includes an explanatory study that explains the influence of principles; accountability and transparency, openness, fairness / non-discrimination and competition against the effectiveness and efficiency of e-procurement. The population in this study is the 300 providers of government Goods/Services registered in the procurement service unit Maluku Province data. Sample determination used in this research is to use purposive sampling technique by using criterion that is; provider of government Goods/Services registered in procurement service unit Maluku Province) with active status, always follow the process of procurement of Goods/Services in procurement service unit Maluku Province at least in the last 6 months and not blacklisted in procurement service unit Maluku Province. Based on this criterion, then the final sample that can be obtained is as much as 79 providers. The analytical tool used to answer the problem and the purpose of research is multiple linear regression analysis.

\section{RESULTS AND DISCUSSION}

Quality Test Instrument Research. Testing instrument in this research is intended to test the validity or validity of the questionnaires used by researchers. Furthermore, this test will be discussed in two parts namely test validity and reliability test as described below. Validity test in this study using Product Moment Person correlation, that the validity of the instrument can be known by comparing the correlation index of Product Moment Person with significant $5 \%$. The results of validity test show that the overall variable of this study can be said to be valid because the correlation value is greater than 0.3 and the significance level is smaller than 0.05 .

Testing reliability of this study using alpha cronbachs where an instrument can be said reliable if it has a value of reliability coefficient greater than or equal to 0.6 means if $\alpha=0.6$ then the instrument can be said reliable. All the variables studied in this study turned out to have a correlation coefficient above 0.60 so that all this research data can be said reliable.

The value of Kolmogorov Smirnov of accountability and transparency is 0.875 , the open principle is 1,590, the principle of Fair/Non-Discriminatory is 1,661, the competitive principle is 1,581 and the effectiveness and efficiency e-procurement of 1,297 which is greater than the value of $D$ table that is 0.150 ( $D$ count> $D$ table) means that data is normally distributed. 
Table 1 - Validity Test Results

\begin{tabular}{|c|c|c|c|c|c|}
\hline Variables & Indicators & Item & $r$ & Sig & Interpretation \\
\hline \multirow{13}{*}{$\begin{array}{c}\text { Principles of Accountability \& } \\
\text { Transparency }\left(\mathrm{X}_{1}\right)\end{array}$} & Reference document preparation & $\mathrm{X}_{1.1}$ & 0.624 & 0.000 & Valid \\
\hline & Performance bond & $\mathrm{X}_{1.2}$ & 0.697 & 0.000 & Valid \\
\hline & \multirow{2}{*}{ Procurement procedure } & $\mathrm{X}_{1.3}$ & 0.679 & 0.000 & Valid \\
\hline & & $\mathrm{X}_{1.4}$ & 0.796 & 0.000 & Valid \\
\hline & \multirow{2}{*}{ Evaluation stage } & $\mathrm{X}_{1.5}$ & 0.733 & 0.000 & Valid \\
\hline & & $\mathrm{X}_{1.6}$ & 0.798 & 0.000 & Valid \\
\hline & Implementation report & $\mathrm{X}_{1.7}$ & 0.753 & 0.000 & Valid \\
\hline & Preparation of Own Price Estimates & $\mathrm{X}_{1.8}$ & 0.644 & 0.000 & Valid \\
\hline & Terms in Document & $\mathrm{X}_{1.9}$ & 0.733 & 0.000 & Valid \\
\hline & $\begin{array}{l}\text { Announcement Addendum } \\
\text { document }\end{array}$ & $X_{1.10}$ & 0.739 & 0.000 & Valid \\
\hline & Schedule & $\mathrm{X}_{1.11}$ & 0.644 & 0.000 & Valid \\
\hline & Data integrity & $\mathrm{X}_{1.12}$ & 0.766 & 0.000 & Valid \\
\hline & Disclaimer & $\mathrm{X}_{1.13}$ & 0.617 & 0.000 & Valid \\
\hline \multirow{3}{*}{ Open Principles (X2) } & Entry requirements & $\mathrm{X}_{2.1}$ & 0.862 & 0.000 & Valid \\
\hline & $\begin{array}{l}\text { Announcement of the General } \\
\text { Procurement Plan }\end{array}$ & $\mathrm{X}_{2.2}$ & 0.800 & 0.000 & Valid \\
\hline & Procurement announcement & $\mathrm{X}_{2.3}$ & 0.798 & 0.000 & Valid \\
\hline \multirow{4}{*}{$\begin{array}{l}\text { Fair/Non-Discriminatory Principle } \\
\qquad(\mathrm{X} 3)\end{array}$} & Entry requirements & $\mathrm{X}_{3.1}$ & 0.787 & 0.000 & Valid \\
\hline & \multirow{2}{*}{ Aanwidjing (job description) } & $\mathrm{X}_{3.2}$ & 0.781 & 0.000 & Valid \\
\hline & & $\mathrm{X}_{3.3}$ & 0.774 & 0.000 & Valid \\
\hline & Technical specifications & $\mathrm{X}_{3.4}$ & 0.808 & 0.000 & Valid \\
\hline \multirow{4}{*}{ The Competitive Principle (X4) } & \multirow{2}{*}{ Compete healthy } & $\mathrm{X}_{4.1}$ & 0.662 & 0.000 & Valid \\
\hline & & $\mathrm{X}_{4.2}$ & 0.641 & 0.000 & Valid \\
\hline & Affiliation & $\mathrm{X}_{4.3}$ & 0.741 & 0.000 & Valid \\
\hline & In accordance with open principles & $\mathrm{X}_{4.4}$ & 0.764 & 0.000 & Valid \\
\hline \multirow{7}{*}{$\begin{array}{c}\text { Effectiveness \& Efficiency E- } \\
\text { Procurement }(Y)\end{array}$} & $\begin{array}{l}\text { Principles of accountability and } \\
\text { transparency }\end{array}$ & $Y_{1.1}$ & 0.747 & 0.000 & Valid \\
\hline & Fair principle & $\mathrm{Y}_{1.2}$ & 0.728 & 0.000 & Valid \\
\hline & The competitive principle & $\mathrm{Y}_{1.3}$ & 0.803 & 0.000 & Valid \\
\hline & Open principle & $\mathrm{Y}_{1.4}$ & 0.762 & 0.000 & Valid \\
\hline & Time effectiveness & $\mathrm{Y}_{1.5}$ & 0.670 & 0.000 & Valid \\
\hline & Cost efficiency & $\mathrm{Y}_{1.6}$ & 0.826 & 0.000 & Valid \\
\hline & IT Ability & $\mathrm{Y}_{1.7}$ & 0.643 & 0.000 & Valid \\
\hline
\end{tabular}

Table 2 - Reliability Test Results

\begin{tabular}{|l|c|c|}
\hline \multicolumn{1}{|c|}{ Variables } & Coefficient Alpha & interpretation \\
\hline Accountability \& Transparency Principle & 0.918 & Reliable \\
\hline Open Principle & 0.756 & Reliable \\
\hline Fair/Non-Discriminatory Principle & 0.794 & Reliable \\
\hline The competitive principle & 0.659 & Reliable \\
\hline Effectiveness \& efficiency of E-Procurement & 0.856 & Reliable \\
\hline
\end{tabular}

Table 3 - Kolmogorov Smirnov Test Results

\begin{tabular}{|c|c|c|c|c|c|c|}
\hline & & PAT & PT & PATD & PB & PEE \\
\hline $\begin{array}{l}\text { N } \\
\text { Normal Parameters } \\
\text { Most Extreme Differences } \\
\text { Kolmogorov-Smirnov Z } \\
\text { Asymp. Sig. (2-tailed) }\end{array}$ & $\begin{array}{l}\text { Mean } \\
\text { Std. Deviation } \\
\text { Absolute } \\
\text { Positive } \\
\text { Negative }\end{array}$ & $\begin{array}{l}79 \\
54.03 \\
6.100 \\
.098 \\
.098 \\
-.070 \\
.875 \\
.428\end{array}$ & $\begin{array}{l}79 \\
12.39 \\
1.605 \\
.179 \\
.179 \\
-.112 \\
1.590 \\
.013\end{array}$ & $\begin{array}{l}79 \\
16.22 \\
2.073 \\
.187 \\
.187 \\
-.117 \\
1.661 \\
.008\end{array}$ & $\begin{array}{l}79 \\
16.28 \\
1.921 \\
.178 \\
.178 \\
-.113 \\
1.581 \\
.013\end{array}$ & $\begin{array}{l}79 \\
28.78 \\
3.429 \\
.146 \\
.146 \\
-.092 \\
1.297 \\
.069\end{array}$ \\
\hline
\end{tabular}

a. Test distribution is Normal.

b. Calculated from data. 
Heteroscedasticity test in this research was done by using Glejser Test which will regress residual absolute value to independent variable (Gozali, 2005). The following is the result of heteroscedasticity testing shown in the table below.

Table 4 - Glejser Test Results

\begin{tabular}{|c|c|c|c|c|c|c|}
\hline \multirow{2}{*}{\multicolumn{2}{|c|}{ Model }} & \multicolumn{2}{|c|}{ Unstandardized Coefficients } & \multirow{2}{*}{$\frac{\text { Standardized Coefficients }}{\text { Beta }}$} & \multirow{2}{*}{$\mathrm{t}$} & \multirow{2}{*}{ Sig. } \\
\hline & & $\mathrm{B}$ & Std. Error & & & \\
\hline \multirow{5}{*}{1} & (Constant) & 670 & 1.305 & & .514 & 611 \\
\hline & PAT & -.086 & .060 & -.610 & -1.426 & 163 \\
\hline & PT & .200 & .138 & .377 & 1.441 & 159 \\
\hline & PATD & .080 & .120 & .219 & .665 & .511 \\
\hline & PB & -.016 & 135 & -.038 & -.116 & .908 \\
\hline
\end{tabular}

This test states that if the independent variable proved not to affect the dependent variable then there is no indication of heteroscedasticity. This is evidenced by the magnitude of the probability significance (sig) above the level of trust 0.05 .

The multicollinearity test of this study uses a view of tolerance and VIF values. The following is the result of multicollinearity testing as seen below;

Table 5 - Multicollinearity Test Results

\begin{tabular}{|l|l|l|}
\hline \multirow{2}{*}{ Model } & \multicolumn{2}{|c|}{ Collinearity Statistics } \\
\cline { 2 - 3 } & Tolerance & VIF \\
\hline Accountability \& Transparency Principle & 0.196 & 5.102 \\
\hline Open Principle & 0.332 & 3.016 \\
\hline Fair/Non-Discriminatory Principle & 0.268 & 3.727 \\
\hline Competitive principle & 0.234 & 4.276 \\
\hline
\end{tabular}

The above data shows that the tolerance value is close to 1 and the VIF value is below 10 which means there is no multicollinearity among the independent variables in this study.

Table 6 - Results of Multiple Linear Regression Test

\begin{tabular}{|c|c|c|c|c|}
\hline Variable & Coefficients & t count & Sig & Interpretation \\
\hline Constant & 0.695 & & & \\
\hline PAT & 0.169 & 3.945 & 0.000 & Significant \\
\hline PT & 0.350 & 2.798 & 0.007 & Significant \\
\hline PATD & 0.435 & 4.032 & 0.000 & Significant \\
\hline PB & 0.550 & 4.416 & 0.000 & Significant \\
\hline Adjusted R Square & \multicolumn{5}{|c|}{0.911} \\
\hline t tabel & \multicolumn{5}{|c|}{1.664} \\
\hline
\end{tabular}

Hypothesis Testing Research:

Hypothesis Testing 1. The results of the first hypothesis testing revealed that the principle of accountability and transparency has a value of $t$ count of 3.945 which is greater than the value of ttable is 1.664 (3.945> 1.664) which means that accept $\mathrm{Ha}$ and reject $\mathrm{HO}$ or the first hypothesis accepted. This result shows that the principle of accountability and transparency has a positive and significant effect on the effectiveness and efficiency of eprocurement in procurement service unit Maluku Province.

Hypothesis Testing 2. The result of the second hypothesis test revealed that open principle has a $t_{\text {count }}$ value of 2,798 which is bigger than $t_{\text {table }}$ value that is 1.664 (2.798> 1.664) which means that reject $\mathrm{HO}$ and accept $\mathrm{Ha}$ or second hypothesis is accepted. These results show that open principle has a positive and significant effect on e-procurement effectiveness and efficiency in procurement service unit Maluku Province.

Hypothesis Testing 3. The result of the third hypothesis test reveals that the principle of Fair/Non-Discriminatory has a value of $t$ count of 4,032 which is greater than the $t_{\text {table }}$ value of $1.664(4,032>1.664)$ which means that accept $\mathrm{Ha}$ and reject $\mathrm{HO}$ or the third hypothesis is 
accepted. These results show that the principle of fair / non-discrimination has a positive and significant effect on the effectiveness and efficiency of e-procurement in procurement service unit Maluku Province.

Hypothesis Testing 4. The result of the fourth hypothesis test shows that the competing principle has a $t_{\text {count }}$ of 4,416 which is bigger than $t_{\text {table }}$ value that is $1.664(4.416>1.664)$ which means that accept $\mathrm{Ha}$ and reject $\mathrm{HO}$ or this last hypothesis is accepted. These results show that the competitive principle has a positive and significant impact on the effectiveness and efficiency of e-procurement in procurement service unit Maluku Province.

\section{DISCUSSION OF RESULTS}

The Influence of Principles of Accountability and Transparency on the Effectiveness and Efficiency of e-Procurement in Procurement Service Unit Maluku Province. The result of the analysis through multiple linear regression showed that the principle of accountability and transparency proved to be positive and significant fall towards the effectiveness and efficiency of e-procurement in procurement service unit Maluku Province. Based on the result of respondent's answer analysis, the role of principle of accountability and transparency in shaping the effectiveness and efficiency of e-procurement in procurement service unit of Maluku Province is caused the work team of procurement service unit Maluku Province announce addendum of procurement document if there is new provision. Any change of the document must be known by all participants so it must be notified by announcement on Electronic Procurement Service Maluku.

Another factor based on the respondents' answers that make this principle affect the effectiveness and efficiency of e-procurement is that all procurement process of goods / service at procurement service unit Maluku Province can be accessed. This reality shows that all providers have the same opportunity to win the tender in Maluku province and with this; the community and other stakeholders can participate in overseeing all stages of the auction process (Iskandar, 2013). In addition, Maluku Provincial procurement service unit is also proven to provide services in a more structured and professional and even open space for refutation to the provider. These results also support the opinion of previous researchers namely; Iskandar, (2013) that e-procurement can also reduce procurement inefficiency by providing greater benefits than the costs incurred.

The Effect of Open Principles on Effectiveness and Efficiency of e-Procurement in Procurement Service Unit Maluku Province. The results of analysis by using multiple linear regressions prove that the open principle proved to have a positive and significant effect on the effectiveness and efficiency of e-procurement in procurement service unit Maluku Province. Furthermore, through the results of the analysis of respondents' answers can be said that the indicators that provide the largest contribution so that this principle affects the effectiveness and efficiency of e-procurement in procurement service unit Maluku Province is an indicator of procurement announcement. These results indicate that the procurement service unit Working Group of Maluku Province has performed its duties in accordance with the prevailing provisions that have displayed the announcement of the procurement process of Goods/Services through the official government website, in the national procurement portal and through local notice boards.

The Influence of Fair/Non-Discriminatory Principle against the Effectiveness and Efficiency of e-Procurement In Procurement Service Unit Maluku Province. The results of the analysis through multiple linear regressions prove that the principle of Fair/NonDiscriminatory proved to have a positive and significant effect on the effectiveness and efficiency of e-procurement in procurement service unit Maluku province. This means that the procurement service unit Working Group of Maluku Province through policymakers in preparing technical specifications has been Fair/Non-Discriminatory or there is no tendency towards certain participants. Basically the requirements of participant participation, aanwidjing (job description) as well

The results of this study are in line with the results of empirical studies by Misbakhul Munir, (2015) and also by Iskandar, (2013) stating that overall fair / non-discriminative 
implementation of e-procurement in Lamongan District, Sukabumi City and Bogor City has been running with both so that indirectly able to optimize the implementation of eprocurement.

The Effect of Competitive Principles on Effectiveness and Efficiency of e-Procurement at Procurement Service Unit Maluku Province. The result of multiple linear regressions analysis proves that the competitive principle has a positive and significant effect on the effectiveness and efficiency of e-procurement in procurement service unit of Maluku Province. These findings prove that the Maluku Provincial Maluku Working Group in determining the winning bidders will still be based on the participants' bidding documents or not because of the "deposit" or intervention from outside parties. This indirectly proves that the competition that occurs among all participants in the procurement of Goods/Services government at procurement service unit Maluku Province is a healthy competition.

\section{CONCLUSION}

Based on the discussion of research results, the conclusions can be submitted are as follows; principles of accountability and transparency, openness, fairness / non-discrimination and competition proved to have a positive and significant impact on the effectiveness and efficiency of e-procurement at procurement service unit Maluku Province. This can be proven through regression coefficient indicating that if the principle of accountability and transparency, openness, fairness / non-discrimination and competition increase, then the increase will be followed by improvement of effectiveness and efficiency of e-procurement at procurement service unit Maluku Province. Thus, it can be said that increasing the principles of accountability and transparency, openness, fairness / non-discrimination and competition will improve the effectiveness and efficiency of e-procurement in procurement service unit Maluku Province.

Limitations encountered throughout the conduct of this study include;

- The sample under study is limited to the procurement unit of Maluku Province only, while the existing procurement service unit in City and Regency in the province of Maluku is not included in this research;

- There are still many variables of effectiveness and efficiency of e-procurement that are not analyzed in this research model.

Implications of future research that can be recommended through this research include;

- Further research can use other variables such as those adopted from the opinion of Luh Putu Resti Mega Artantri, et al., (2016) which states that several factors related to the procurement process of government Goods/Services such as individual factors in the form of greed and need such as the commitment of members of the organization to not to cheat, and the provision of appropriate compensation to the procurement of goods/services;

- We recommend that further research should add samples that can be obtained from City and District Procurement Units in the Province of Maluku.

\section{REFERENCES}

1. Agustina Ika Iskandar, (2013) Procurement Analysis of Goods/Services in Sukabumi City Government, Bogor City Government and Government Procurement Policy Institution, Thesis, Master of Planning and Public Policy, University of Indonesia.

2. Badzlina Daroyani Novitaningrum, (2014) Accountability and Transparency Procurement of Government Goods and Services Through Electronic Procurement (Best Practice in Surabaya City Government), Jurnal Kebijakan dan Manajemen Publik, 2(1) ISSN 2303 $341 \mathrm{X}$

3. Florensia Br. KJaro-Karo, (2012) Efficiency or Savings in Use of E-Procurement in Yogyakarta City Government, Thesis, University of Gajah Mada. 
4. Grant, R.W., \& Keohane, R.O., (2005) Accountability and Abuses of Power in World of Politics, the American Political Science Review, 99, 29-43.

5. Imam Ghozali, (2005) Application of Multivariate Analysis with SPSS Program, Edisi Ketiga, Badan Penerbit Universitas Diponegoro, Semarang.

6. Jennifer Rubinstein, (2007) Accountability in an Unequal World, the Journal of Politics, 69, 616-632.

7. Jensen, M.C., \& Meckling. W.H., (1976) Theory of the Firm; Managerial Behaviour, Agency Cost and Ownership Structure, Journal of Financial Economics, 3, 305-360.

8. Luh Putu Resti Mega Artantri, Lilik Handajani dan Endar Pituringsih, (2016) Role of EProcurement Against Prevention of Fraud on Procurement of Goods/Services of Local Government in Lombok Island, NeO Bis, 10(1), June 2016.

9. Misbakhul Munir, (2015) Electronic Procurement Effectiveness in Procurement of Goods/Services in Lamongan District Government Environment, Thesis, Surabaya State University.

10. Organisation for Economic Cooperation and Development, (2007) Integrity in Public Procurement, OECD Publishing, Paris.

11. Panayiotou, N.A., Gayaialis, S.P., Tatsiopoulos, I.P., (2004) an E-Procurement System for Governmental Purchasing, International Journal of Production Economics, Vol. 90, pp. 79-102.

12. Peraturan Presiden Nomor 54 tahun 2010 Presidential Regulation No. 54 of 2010 on Procurement of Government Goods/services.

13. Peraturan Presiden Nomor 70 tahun 2012 Presidential Regulation No. 70 of 2012 on the Second Amendment to Presidential Regulation No. 54 of 2010.

14. Peraturan Presiden Republik Indonesia Nomor 4 Tahun 2015 Regulation of the President of the Republic of Indonesia Number 4 Year 2015 Concerning Amendment to Presidential Regulation No. 70 of 2012.

15. Schapper, P.R., Malta, J.N., \& Gilbert, D.L., (2009) Analytical Framework for Management and Reform of Public Procurement, In Khi V, Thai International Handbook of Public Procurement (pp.87-104), Florida: Taylor and Francis Group.

16. Stirton L, \& Lodge M., (2001) Tranparency Mechanism; Building Publicness into Public, Journal of Law \& Society, 28, pp. 471-489.

17. V.K. Narendira Kumar \& B. Srinivasan, (2013) Implementation and Performance Effect on Electronic Procurement and its Ship Management Companies, I.J. Information Engineering and Electronic Business, 2013, 5, pp. 10-16.

18. Wahyu Hary Wijaya, Retno Indryani, dan Yusronia Eka Putri, (2011) Study of Implementation of E-Procurement in Procurement Process in Surabaya City Government, Thesis, Sepuluh Nopember Institute of Technology Surabaya. 